Jurnal Riset Kesehatan

http://ejournal.poltekkes-smg.ac.id/ojs/index.php/jrk

\title{
PEMETAAN SEBARAN SEPULUH BESAR PENYAKIT DI PUSAT KESEHATAN MASYARAKAT MOJOSONGO KABUPATEN BOYOLALI BERBASIS SISTEM INFORMASI GEOGRAFIS
}

\author{
Dito Yogo Waskito*) ; Lily Kresnowati ; Subinarto \\ Jurusan Rekam Medis dan Informasi Kesehatan; Poltekkes Kemenkes Semarang \\ Jl. Tirto Agung; Pedalangan; Banyumanik; Semarang
}

\begin{abstract}
Abstrak
Penelitian ini bertujuan untuk mengetahui sepuluh besar penyakit dan memetakan sebaran sepuluh besar penyakit di pusat kesehatan masyarakat Mojosongo dengan berbasis sistem informasi geografis (SIG). Penggunaan SIG dibidang kesehatan yaitu sebagai penyedia data atribut dan spasial yang mampu menggambarkan distribusi penderita suatu penyakit, pola atau model sebaran penyakit dan fasilitas pendukungnya. Melalui pemetaan sebaran penyakit diharap informasi tentang titik dan angka sebaran penyakit dapat lebih mudah diakses sebagai pertimbangan pengambilan keputusan. Penelitian ini merupakan penelitian deskriptif dengan pendekatan cross-sectional. Pengambilan data dengan cara mengambil data sekunder yang telah terdapat dalam sistem informasi Puskesmas. Proses pengolahan dan pembuatan Peta menggunakan aplikasi ArcGis. 10.1. Dari penelitian ini, didapatkan dua hasil sebagai berikut: sepuluh besar penyakit yang sering muncul di Puskesmas Mojosongo yaitu Influenza, Defisiensi Vitamin, Gastritis, Sakit Kepala, Hipertensi, Diare, Faringitis, Sakit Gigi, Asma, dan Konjungtivitis, dengan jumlah total kasus sebanyak 26.647 kasus. Serta diperoleh hasil peta sebaran sepuluh besar penyakit di Puskesmas Mojosongo pada dengan berbasis Sistem Informasi Geografis. Desa Jurug menjadi wilayah yang paling sering diklasifikasikan sebagai desa dengan kejadian kasus penyakit sangat tinggi dan Desa Butuh menjadi desa paling sering diklasifikasikan sebagai sebagai desa dengan kejadian kasus penyakit sangat rendah.
\end{abstract}

Kata Kunci: Penyakit; Sebaran; Pemetaan; Sistem Informasi Geografis; Puskesmas

\begin{abstract}
This research is aimed to mapping the top ten highest incidence of disease in the Puskesmas Mojosongo using geographic information systems (GIS). GIS is used in health sector to provide attributed and spatial data of the distribution of patients, pattern or model of disease distribution and supporting facilities. By mapping the spread of the disease, it is hoped that information on the spot of locations and number of cases of disease can be easier to access as decision-making considerations. This research is a descriptive research with cross-sectional approach. Data collecting is done by taking secondary data that already exist in health information system of Puskesmas. The Map is processed and made by using ArcGis application. 10.1. From this research, two outcomes were obtained: the top ten diseases that often arises in Mojosongo community health centers is Influenza, Deficiency of Vitamin, Gastritis, Headache, Hypertension, Diarrhea, Pharyngitis, Toothache, Asthma, and Conjunctivitis, with the total number of 26,647 cases. And the other result is the map of the distribution of top ten diseases in the area of Mojosongo community health center based on geographic information system. Jurug village became the most frequently classified area with several very high incidence of disease and Butuh village being the most frequently classified village with very low incidence of disease.
\end{abstract}

Keywords: Disease; Distribution; Mapping; Geographic Information System; Puskesmas

\section{Pendahuluan}

Teknologi informasi dan komunikasi dewasa ini telah menjadi sebuah kebutuhan

*) Dito Yogo Waskito

E-mail: ditoyogowaskito@gmail.com disegala aspek kehidupan dan bukan lagi hanya menjadi sebuah keinginan, tidak terkecuali di bidang kesehatan. 
Penerapan paradigma sehat pada Program Indonesia Sehat yang berfokus pada penguatan upaya promotif dan preventif yang sesuai dengan sasaran pokok rencana pembangunan jangka menengah nasional (RPJMN) tahun 2015-2019 yaitu upaya meningkatkan pengendalian penyakit, yang di mulai dari tingkat pelayanan kesehatan pertama. Berdasarkan Peraturan Menteri Kesehatan Republik Indonesia Nomor 44 tahun 2016 Tentang Pedoman Manajemen Puskesmas bahwa untuk melaksanakan upaya kesehatan baik upaya kesehatan masyarakat tingkat pertama maupun upaya kesehatan perseorangan tingkat pertama dibutuhkan manajemen Puskesmas yang dilakukan secara terpadu dan berkesinambungan agar menghasilkan kinerja Puskesmas yang efektif dan efisien sesuai dengan fungsinya yaitu untuk mengelola dan merencanakan pembangunan kesehatan diwilayah kerjanya. Oleh karena itu pemanfaatan data, khususnya data penyakit, menjadi sangat penting bagi pemangku kepentingan dalam proses pengambilan keputusan.

Pemanfaatan data oleh Puskesmas dalam upaya menyelenggarakan pelayanan kesehatan promotif dan preventif dengan baik dapat dilakukan dengan melakukan surveilans Epidemiologi melalui rangkaian proses mengumpulkan, menganalisis, menginterpretasi, menerapkan, dan menghubungkan dengan praktik-praktik kesehatan masyarakat sehingga data yang diperoleh dapat di manfaatkan untuk menguraikan dan memantau suatu peristiwa kesehatan agar dapat dilakukan penanggulangan yang efektif dan efesien terhadap masalah kesehatan masyarakat tersebut.

Sistem Informasi Geografis (SIG) digunakan untuk mengumpulkan, mengelola, memanipulasi dan memvisualisasikan data spasial (keruangan), Penggunaan SIG salah satunya dibidang kesehatan yaitu sebagai penyedia data atribut dan spasial yang mampu menggambarkan distribusi penderita suatu penyakit, pola atau model sebaran penyakit, distribusi unit-unit jumlah tenaga medis, pelayanan kesehatan dan fasilitas pendukungnya. Melalui sistem pemetaan sebaran penyakit diharap informasi tentang titik dan angka sebaran penyakit dapat lebih mudah diakses.

\section{Metode}

Penelitian ini merupakan penelitian deskriptif dengan pendekatan cross-sectional. Pengambilan data dengan cara mengambil data sekunder yang telah terdapat dalam sistem informasi puskesmas berupa data administrasi dan data klinis pasien pada periode tahun 2016, untuk memperoleh data sepuluh besar penyakit di Puskesmas Mojosongo periode tahun 2016.

Metode pengumpulan data yang dilakaukan peneliti yaitu dengan teknik pengamatan secara tidak langsung yaitu dengan mengambil data hasil pengamatan dari peneliti lain atau dalam hal ini data dalam sistem informasi puskesmas.

Data sekunder yang digunakan yaitu: (1) Data dasar Puskesmas Mojosongo (2) Peta Rupa Bumi Indonesia Daerah Kecamatan Mojosongo, digunakan untuk mengetahui data sebaran penyakit (3) Data klinis dan data administrasi pasien Puskesmas Mojosongo tahun 2016.

Tahap pengumpulan data yang dilakukan dalam penelitian sebagai berikut: (1) Mengumpulkan citra spasial daerah Kecamatan Mojosongo, Kabupaten Boyolali perekaman tahun 2016 dari google earth. (2) Mengumpulkan data sekunder yang akan digunakan dalam analisis pemetaan sebaran penyakit, seperti data administrasi pasien, data klinis pasien, data batas administrasi wilayah, data jaringan jalan, dan data jaringan sungai.

Pengolahan data dalam penelitian ini menggunakan Software ArcGIS 10.1. Tahap pengolahan data yang dilakukan dalam penelitian sebagai berikut: (1) Memasukkan data sekunder kedalam atribut di software ArcGIS. (2) Melakukan pengkelasan berdasarkan besarnya jumlah kasus sepuluh besar penyakit di wilayah kerja Puskesmas Mojosongo.

Dalam penelitian ini penulis akan mengidentifikasi sepuluh besar penyakit yang diperoleh dari data klinis dan data administrasi pasien, selanjutnya menjumlah sepuluh besar penyakit di setiap desa sehingga akan diketahui total jumlah kasus disetiap desa, selanjutnya di identifikasi sepuluh besar desa dengan kasus penyakit tertinggi. Setelah itu penulis akan membagi sebaran penyakit menjadi lima kelas yang dibedakan melalui warna. Sehingga akan diketahui desa yang memiliki jumlah sebaran tertinggi berdasarkan kelasnya.

Penyajian data dilakukan melalui proses layout terhadap peta yang telah dibuat menggunakan Software ArcGIS 10.1. Hasil penelitian berupa peta sebaran sepuluh besar penyakit di Puskesmas Mojosongo tahun 2016. 
Analisis data menggunakan analisis deskriptif yang dijelaskan dalam bentuk peta dan diagram tegak/lingkaran sebagai informasi tambahan mengenai jumlah dan sebaran penyakit.

\section{Hasil dan Pembahasan}

Data Sepuluh Besar Penyakit Berdasarkan Data Kesakitan Pasien Tahun 2016

Tinggi kasus sebuah penyakit dapat dilihat dari besarnya kejadian kasus yang ditangani oleh Puskesmas Mojosongo, Data sepuluh besar penyakit di Puskesmas Mojosongo diperoleh dari proses pencatatan setiap kasus yang ditangani di Puskesmas Induk dan Puskesmas Pembantu disetiap desa diwilayah kerjanya. Jumlah kasus dan jenis kasus yang masuk dalam kategori sepuluh besar penyakit paling sering terjadi pada tahun 2016 dapat dilihat pada Tabel 1.

Tabel 1. Sepuluh Besar Penyakit di Puskesmas Mojosongo

\begin{tabular}{cccc}
\hline \hline No & Penyakit & $\begin{array}{c}\text { Kode } \\
\text { ICD } \\
\mathbf{1 0}\end{array}$ & Jumlah (Kasus) \\
\hline $\mathbf{1}$ & Influenza & J11 & 8.930 \\
$\mathbf{2}$ & Defisiensi Vitamin & E56 & 5.673 \\
$\mathbf{3}$ & Gastritis & K29 & 3.929 \\
$\mathbf{4}$ & Sakit Kepala & G43 & 2.515 \\
$\mathbf{5}$ & Hipertensi & J10 & 2.325 \\
$\mathbf{6}$ & Diare & A09 & 969 \\
$\mathbf{7}$ & Faringitis & J02 & 612 \\
$\mathbf{8}$ & Sakit Gigi & K04 & 598 \\
$\mathbf{9}$ & Asma & J45 & 590 \\
$\mathbf{1 0}$ & Konjungtivitis & H10 & 506 \\
\hline \hline
\end{tabular}

Diketahui sepuluh jenis kasus yang sering muncul pada tahun 2016 seperti influenza, defisiensi vitamin, gastritis, sakit kepala, hipertensi, diare, faringitis, sakit gigi, asma, dan konjungtivitis.

Sebaran Penyakit Influenza di Puskesmas Mojosongo

Influenza merupakan kasus kesakitan yang paling tinggi yang terjadi diseluruh wilayah kerja Puskesmas Mojosongo. Sebaran penyakit Influenza dapat dilihat pada Tabel 2. berikut.
Tabel 2. Sebaran Kasus Penyakit Influenza

\begin{tabular}{ccc}
\hline \hline No & Desa & Penyakit (Kasus) \\
\hline 1 & Karangnongko & 366 \\
2 & Manggis & 643 \\
3 & Madu & 1.386 \\
4 & Dlingo & 432 \\
5 & Jurug & 1.254 \\
6 & Singosari & 1.316 \\
7 & Tambak & 684 \\
8 & Kragilan & 372 \\
9 & Butuh & 15 \\
10 & Mojosongo & 1.405 \\
11 & Brajan & 262 \\
12 & Metuk & 445 \\
13 & Kemiri & 350 \\
\hline \hline
\end{tabular}

Diketahui bahwa untuk kasus penyakit influenza terjadi secara merata diseluruh desa yang menjadi wilayah kerja Puskesmas Mojosongo. Diketahui bahwa Desa Mojosongo merupakan wilayah dengan tingkat kasus penyakit influenza paling tinggi dibanding dengan desa-desa lainnya dengan jumlah kasus sebanyak 1.405 kasus pada tahun 2016.

Penghitungan Kelas dilakukan secara otomatis dalam Arcgis. Dengan berdasarkan rumus equal interval:

$$
\begin{aligned}
\text { Kelas Sebaran } & =\frac{N T \max -N T \min }{5} \\
\text { Kelas Sebaran } & =\frac{1.405-15}{5} \\
\text { Kelas Sebaran } & =\frac{1.390}{5}
\end{aligned}
$$

Kelas Sebaran $=278$ kasus

Jadi, dapat di ketahui bahwa disetiap kelas memiliki rentang kasus sebanyak 278 kasus. Sehingga selanjutnya sebaran penyakit influenza yang terjadi di wilayah kerja Puskesmas Mojosongo pada tahun 2016, dapat diolah menjadi informasi berupa peta yang di klasifikasi 5 kelas sebaran penyakit dengan menggunakan sistem informasi Geografis. Yang hasilnya dapat dilihat pada Gambar 1 berikut: 


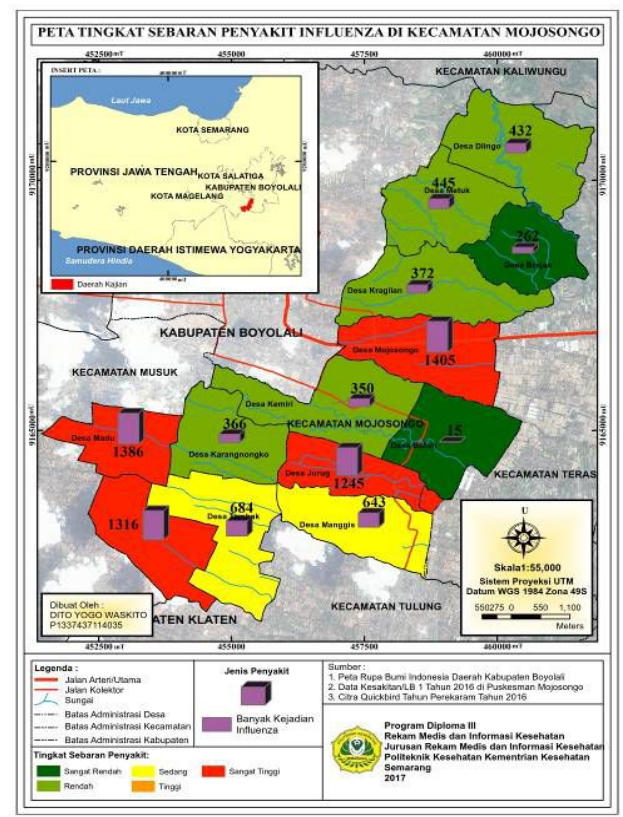

Gambar 1. Peta Sebaran Penyakit Influenza

Tingginya kasus influenza di wilayah Puskesmas Mojosongo menjadi peringatan untuk mewaspadai tingginya potensi penyebaran virus penyebab penyakit influenza di wilayah kerja Puskesmas Mojosongo.

Sebaran Kasus Defisiensi Vitamin di Puskesmas Mojosongo

Kasus defisiensi vitaminin terjadi cukup tinggi dimana terdapat 5.673 kasus pada tahun 2016 yang menyebar diseluruh wilayah kerja Puskesmas Mojosongo. Dan sebaran jumlah kasus Defisiensi Vitamin di Puskesmas Mojosongo dapat dilihat pada Tabel 3.3 Berikut.

Tabel 3. Sebaran Kasus Defisiensi Vitamin

\begin{tabular}{clc}
\hline \hline No & \multicolumn{1}{c}{ Desa } & Penyakit (Kasus) \\
\hline 1 & Karangnongko & 194 \\
2 & Manggis & 394 \\
3 & Madu & 664 \\
4 & Dlingo & 275 \\
5 & Jurug & 1.700 \\
6 & Singosari & 502 \\
7 & Tambak & 705 \\
8 & Kragilan & 111 \\
9 & Butuh & 11 \\
10 & Mojosongo & 264 \\
11 & Brajan & 207 \\
12 & Metuk & 418 \\
13 & Kemiri & 228 \\
\hline \hline
\end{tabular}

Penghitungan Kelas dilakukan secara otomatis dalam Arcgis. Dengan berdasarkan rumus equal interval:

$$
\begin{aligned}
\text { Kelas Sebaran } & =\frac{N T \max -N T \min }{5} \\
\text { Kelas Sebaran } & =\frac{1.700-11}{5} \\
\text { Kelas Sebaran } & =\frac{1.689}{5} \\
\text { Kelas Sebaran } & =337 \text { kasus }
\end{aligned}
$$

Jadi, dapat di ketahui bahwa disetiap kelas memiliki rentang kasus sebanyak 337 kasus. Sehingga selanjutnya sebaran penyakit defisiensi vitamin yang terjadi di wilayah kerja Puskesmas Mojosongo pada tahun 2016, dapat diolah menjadi informasi berupa peta yang di klasifikasi 5 kelas sebaran penyakit dengan menggunakan sistem informasi Geografis. Yang hasilnya dapat dilihat pada Gambar 3.2 berikut.

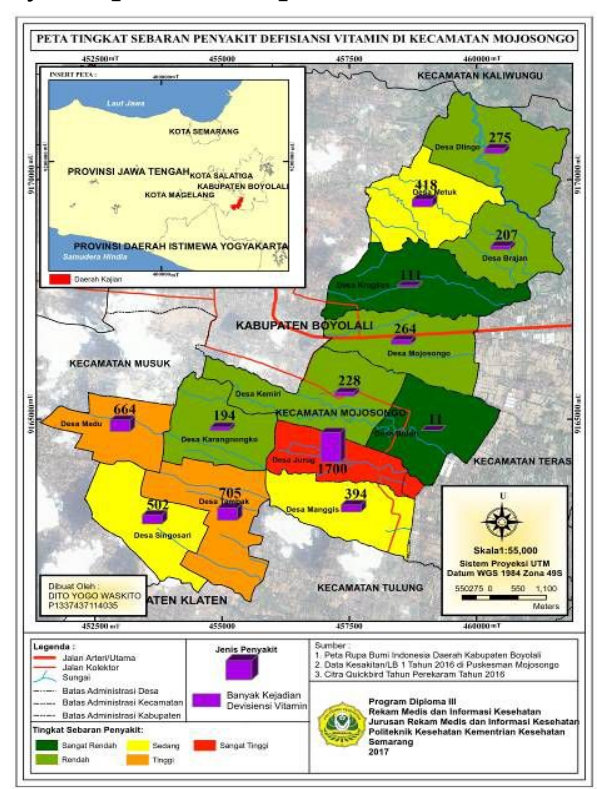

Gambar 2. Peta Sebaran Penyakit Defisiensi Vitamin

Sebaran Kasus Gastritis di Puskesmas Mojosongo

Sebaran penyakit gastritis di setiap desa diwilayah kerja Puskesmas Mojosongo dapat dilihat pada Tabel 4 berikut:

Tabel 4. Sebaran Kasus Gastritis

\begin{tabular}{clc}
\hline \hline & & \\
No & \multicolumn{1}{c}{ Desa } & Penyakit (Kasus) \\
\hline 1 & Karangnongko & 102 \\
2 & Manggis & 99 \\
3 & Madu & 385 \\
4 & Dlingo & 38 \\
\hline \hline
\end{tabular}




\begin{tabular}{clc}
\hline \hline 5 & Jurug & 1.372 \\
6 & Singosari & 486 \\
7 & Tambak & 412 \\
8 & Kragilan & 48 \\
9 & Butuh & 2 \\
10 & Mojosongo & 358 \\
11 & Brajan & 113 \\
12 & Metuk & 347 \\
13 & Kemiri & 167 \\
\hline \hline
\end{tabular}

Penghitungan Kelas dilakukan secara otomatis dalam Arcgis. Dengan berdasarkan rumus equal interval:

$$
\begin{aligned}
& \text { Kelas Sebaran }=\frac{N T \text { max }-N T \text { min }}{5} \\
& \text { Kelas Sebaran }=\frac{1.372-2}{5} \\
& \text { Kelas Sebaran }=\frac{1.370}{5} \\
& \text { Kelas Sebaran }=274 \text { kasus }
\end{aligned}
$$

Jadi, dapat di ketahui bahwa disetiap kelas memiliki rentang kasus sebanyak 274 kasus. Sehingga data diatas dapat diolah menjadi informasi berupa peta yang di klasifikasi 5 kelas sebaran penyakit dengan menggunakan sistem informasi geografis. Yang hasilnya dapat dilihat pada Gambar 3. berikut:

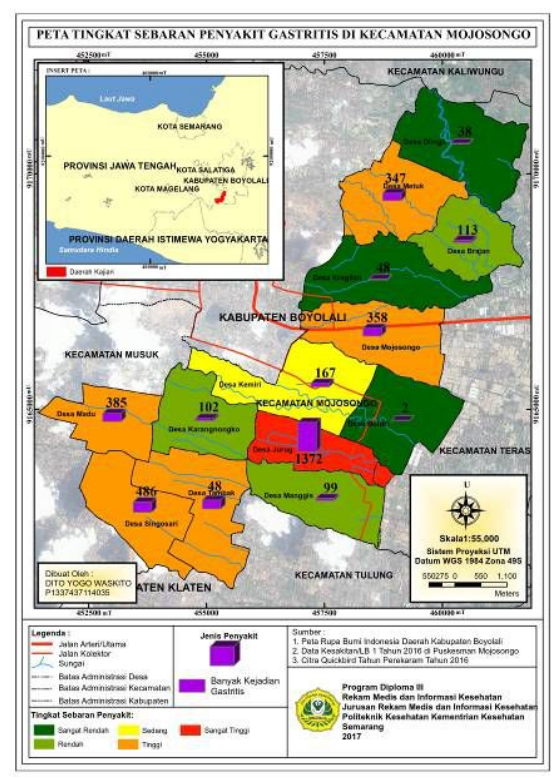

Gambar 3. Peta Sebaran Penyakit Gastritis

Sebaran kasus sakit kepala di Puskesmas Mojosongo

Selama kurun waktu satu tahun pada periode tahun 2016 ditemukan sebanyak 2515 kasus sakit kepala diseluruh wilayah kerja Puskesmas Mojosongo. Sebaran kasus sakit kepala di wilayah kerja Puskesmas Mojosongo merata di seluruh wilayah. Sebaran Kasus kepala dapat dilihat pada Tabel 5. Berikut:

Tabel 5. Sebaran Kasus Sakit Kepala

\begin{tabular}{clc}
\hline \hline No & \multicolumn{1}{c}{ Desa } & Penyakit (Kasus) \\
& & \\
\hline 1 & Karangnongko & 128 \\
2 & Manggis & 261 \\
3 & Madu & 143 \\
4 & Dlingo & 196 \\
5 & Jurug & 321 \\
6 & Singosari & 461 \\
7 & Tambak & 169 \\
8 & Kragilan & 79 \\
9 & Butuh & 4 \\
10 & Mojosongo & 139 \\
11 & Brajan & 72 \\
12 & Metuk & 419 \\
13 & Kemiri & 123 \\
\hline \hline
\end{tabular}

Penghitungan Kelas dilakukan secara otomatis dalam Arcgis. Dengan berdasarkan rumus equal interval:

$$
\begin{aligned}
\text { Kelas Sebaran } & =\frac{N T \max -N T \text { min }}{5} \\
\text { Kelas Sebaran } & =\frac{461-4}{5} \\
\text { Kelas Sebaran } & =\frac{457}{5} \\
\text { Kelas Sebaran } & =91 \text { kasus }
\end{aligned}
$$

Jadi, dapat di ketahui bahwa disetiap kelas memiliki rentang kasus sebanyak 91 kasus. Sehingga selanjutnya sebaran penyakit sakit kepala yang terjadi di wilayah kerja Puskesmas Mojosongo pada tahun 2016, dapat diolah menjadi informasi berupa sebaran penyakit Yang hasilnya dapat dilihat pada Gambar 4. berikut:

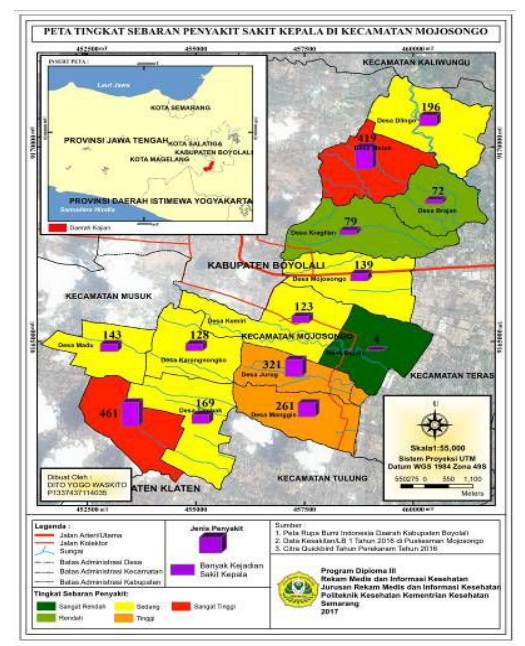

Gambar 4. Peta Sebaran Penyakit Sakit Kepala 
Sebaran Kasus Hipertensi di Puskesmas Mojosongo

Selama periode tahun 2016 terjadi sebanyak 2.325 kasus hipertensi di seluruh wilayah kerja Puskesmas Mojosongo. Sebaran kasus hipertensi dapat dilihat pada Tabel 6 . berikut:

Tabel 6. Sebaran Kasus Hipertensi

\begin{tabular}{clc}
\hline \hline No & \multicolumn{1}{c}{ Desa } & Penyakit (Kasus) \\
& & 67 \\
\hline 1 & Karangnongko & 186 \\
2 & Manggis & 210 \\
3 & Madu & 270 \\
4 & Dlingo & 311 \\
5 & Jurug & 143 \\
6 & Singosari & 537 \\
7 & Tambak & 8 \\
8 & Kragilan & 8 \\
9 & Butuh & 208 \\
10 & Mojosongo & 71 \\
11 & Brajan & 218 \\
12 & Metuk & 88 \\
13 & Kemiri & \\
\hline \hline
\end{tabular}

Penghitungan Kelas dilakukan secara otomatis dalam Arcgis. Dengan berdasarkan rumus equal interval:

$$
\begin{aligned}
\text { Kelas Sebaran } & =\frac{N T \max -N T \min }{5} \\
\text { Kelas Sebaran } & =\frac{537-8}{5} \\
\text { Kelas Sebaran } & =\frac{529}{5} \\
\text { Kelas Sebaran } & =106 \text { kasus }
\end{aligned}
$$

Jadi, dapat di ketahui bahwa disetiap kelas memiliki rentang kasus sebanyak 106 kasus. Sehingga selanjutnya sebaran penyakit hipertensi yang terjadi di wilayah kerja Puskesmas Mojosongo pada tahun 2016, dapat diolah menjadi informasi berupa peta yang di klasifikasi 5 kelas sebaran penyakit dengan menggunakan sistem informasi Geografis. Yang hasilnya dapat dilihat pada Gambar 5. berikut:

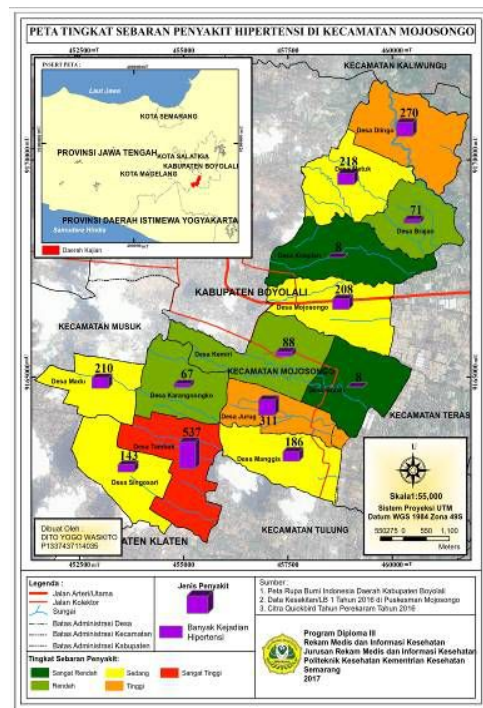

Gambar 5. Peta Sebaran Penyakit Hipertensi

Sebaran Kasus Diare di Puskesmas Mojosongo

Selama periode tahun 2016 diketahui sebanyak 969 kasus diare di seluruh wilayah kerja Puskesmas Mojosongo. Sebaran banyaknya kasus yang terjadi di setiap desa dapat dilihat pada Tabel 7. berikut:

Tabel 7. Sebaran Kasus Diare

\begin{tabular}{clc}
\hline \hline No & \multicolumn{1}{c}{ Desa } & Penyakit (Kasus) \\
\hline 1 & Karangnongko & 63 \\
2 & Manggis & 51 \\
3 & Madu & 150 \\
4 & Dlingo & 38 \\
5 & Jurug & 97 \\
6 & Singosari & 173 \\
7 & Tambak & 93 \\
8 & Kragilan & 32 \\
9 & Butuh & 3 \\
10 & Mojosongo & 128 \\
11 & Brajan & 43 \\
12 & Metuk & 53 \\
13 & Kemiri & 45 \\
\hline \hline
\end{tabular}

Penghitungan Kelas dilakukan secara otomatis dalam Arcgis. Dengan berdasarkan rumus equal interval:

$$
\begin{aligned}
\text { Kelas Sebaran } & =\frac{N T \max -N T \min }{5} \\
\text { Kelas Sebaran } & =\frac{173-3}{5} \\
\text { Kelas Sebaran } & =\frac{170}{5} \\
\text { Kelas Sebaran } & =34 \text { kasus }
\end{aligned}
$$


Jadi, dapat di ketahui bahwa disetiap kelas memiliki rentang kasus sebanyak 34 kasus. Sehingga selanjutnya sebaran penyakit diare yang terjadi di wilayah kerja Puskesmas Mojosongo pada tahun 2016, dapat diolah menjadi informasi berupa peta yang di klasifikasi 5 kelas sebaran penyakit dengan menggunakan sistem informasi Geografis. Yang hasilnya dapat dilihat pada Gambar 6. berikut:

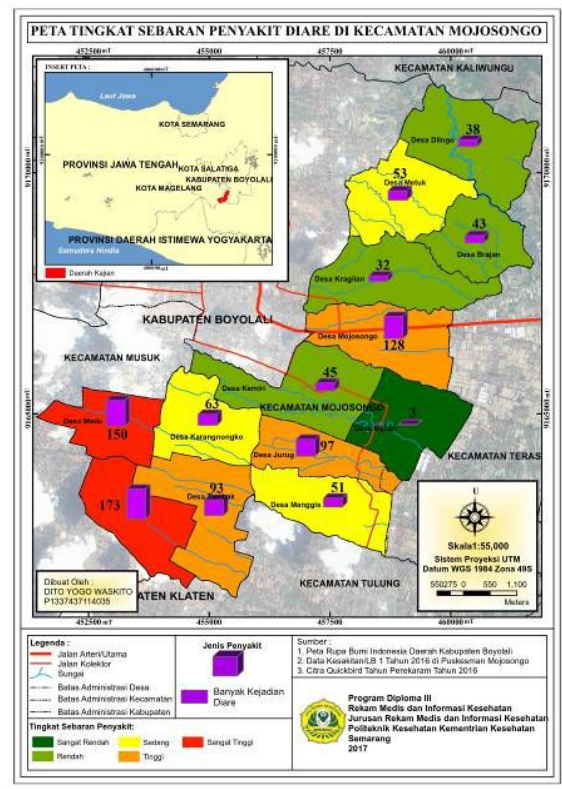

Gambar 6. Peta Sebaran Penyakit Diare

Sebaran Kasus Faringitis di Puskesmas Mojosongo

Pada periode tahun 2016 dengan kasus sebanyak 612 kasus. Sebaran banyaknya kasus yang terjadi di setiap desa dapat dilihat pada Tabel 8. berikut:

Tabel 8. Sebaran Kasus Faringitis

\begin{tabular}{clc}
\hline \hline No & \multicolumn{1}{c}{ Desa } & Penyakit (Kasus) \\
& & 0 \\
\hline 1 & Karangnongko & 3 \\
2 & Manggis & 73 \\
3 & Madu & 23 \\
4 & Dlingo & 275 \\
5 & Jurug & 0 \\
6 & Singosari & 166 \\
7 & Tambak & 0 \\
8 & Kragilan & 1 \\
9 & Butuh & 37 \\
10 & Mojosongo & 0 \\
11 & Brajan & 34 \\
12 & Metuk & 0 \\
13 & Kemiri & \\
\hline \hline
\end{tabular}

Penghitungan Kelas dilakukan secara otomatis dalam Arcgis. Dengan berdasarkan rumus equal interval:

$$
\begin{aligned}
\text { Kelas Sebaran } & =\frac{N T \max -N T \min }{5} \\
\text { Kelas Sebaran } & =\frac{275-0}{5} \\
\text { Kelas Sebaran } & =\frac{275}{5} \\
\text { Kelas Sebaran } & =55 \text { kasus }
\end{aligned}
$$

Jadi, dapat di ketahui bahwa disetiap kelas memiliki rentang kasus sebanyak 55 kasus. Sehingga selanjutnya sebaran penyakit faringitis yang terjadi di wilayah kerja Puskesmas Mojosongo pada tahun 2016, dapat diolah menjadi informasi berupa peta yang di klasifikasi 5 kelas sebaran penyakit dengan menggunakan sistem informasi Geografis. Yang hasilnya dapat dilihat pada Gambar 7. berikut:

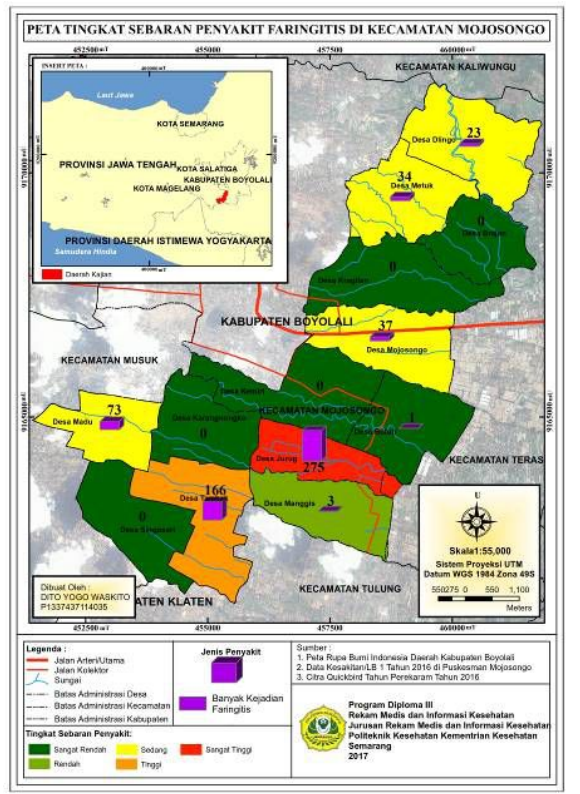

Gambar 7. Peta Sebaran Penyakit Faringitis

Sebaran Kasus Sakit Gigi di Puskesmas Mojosongo

Kasus gigi menempati ke tujuh kasus paling sering muncul dengan jumlah kasus sebanyak 598 kasus pada periode tahun 2016. Data sebaran kasus sakit gigi dapat dilihat pada Tabel 9. berikut:

\begin{tabular}{llc}
\multicolumn{2}{c}{ Tabel 9. Sebaran Kasus Sakit Gigi } \\
\hline \hline No & \multicolumn{1}{c}{ Desa } & Penyakit (Kasus) \\
& & \\
\hline 1 & Karangnongko & 33 \\
2 & Manggis & 6 \\
3 & Madu & 107 \\
4 & Dlingo & 29 \\
\hline
\end{tabular}




\begin{tabular}{clc}
\hline \hline 5 & Jurug & 85 \\
6 & Singosari & 57 \\
7 & Tambak & 95 \\
8 & Kragilan & 31 \\
9 & Butuh & 0 \\
10 & Mojosongo & 37 \\
11 & Brajan & 33 \\
12 & Metuk & 53 \\
13 & Kemiri & 32 \\
\hline \hline
\end{tabular}

Penghitungan Kelas dilakukan secara otomatis dalam Arcgis. Dengan berdasarkan rumus equal interval:

$$
\begin{aligned}
& \text { Kelas Sebaran }=\frac{N T \max -N T \min }{5} \\
& \text { Kelas Sebaran }=\frac{107-0}{5} \\
& \text { Kelas Sebaran }=\frac{107}{5}
\end{aligned}
$$

Kelas Sebaran $=21$ kasus

Jadi, dapat di ketahui bahwa disetiap kelas memiliki rentang kasus sebanyak 21 kasus. Sehingga selanjutnya sebaran penyakit sakit gigi yang terjadi di wilayah kerja Puskesmas Mojosongo pada tahun 2016, dapat diolah menjadi informasi berupa peta yang di klasifikasi 5 kelas sebaran penyakit dengan menggunakan sistem informasi Geografis. Yang hasilnya dapat dilihat pada Gambar 3.8 berikut.

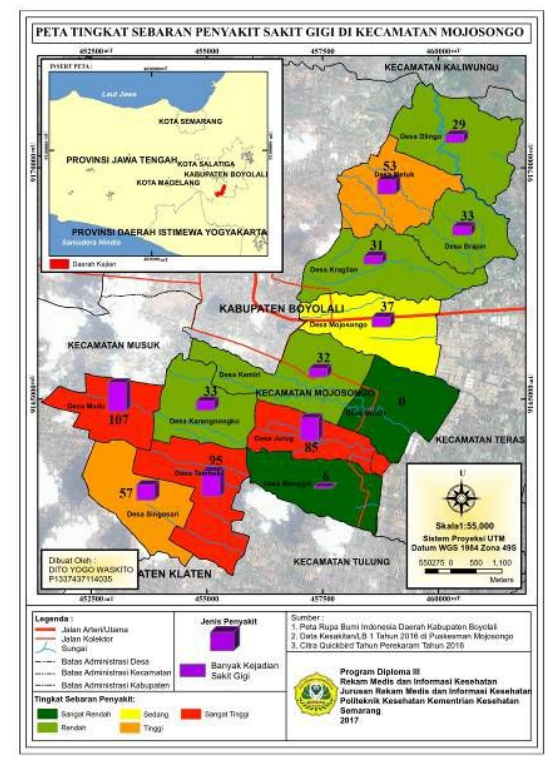

Gambar 8. Peta Sebaran Penyakit Faringitis

Sebaran Kasus Asma di Puskesmas Mojosongo

Kasus asma termasuk sepuluh besar yang sering muncul di Puskesmas Mojosongo pada periode tahun 2016 dengan jumlah kasus sebanyak 590 kasus. Data sebaran kasus asma dapat dilihat pada Tabel 10. berikut:

Tabel 10. Sebaran Kasus Asma

\begin{tabular}{clc}
\hline \hline No & \multicolumn{1}{c}{ Desa } & Penyakit (Kasus) \\
& & \\
\hline 1 & Karangnongko & 19 \\
2 & Manggis & 75 \\
3 & Madu & 14 \\
4 & Dlingo & 160 \\
5 & Jurug & 53 \\
6 & Singosari & 65 \\
7 & Tambak & 7 \\
8 & Kragilan & 3 \\
9 & Butuh & 64 \\
10 & Mojosongo & 1 \\
11 & Brajan & 129 \\
12 & Metuk & 0 \\
13 & Kemiri & \\
\hline \hline
\end{tabular}

Penghitungan Kelas dilakukan secara otomatis dalam Arcgis. Dengan berdasarkan rumus equal interval:

$$
\begin{aligned}
\text { Kelas Sebaran } & =\frac{N T \max -N T \min }{5} \\
\text { Kelas Sebaran } & =\frac{160-0}{5} \\
\text { Kelas Sebaran } & =\frac{160}{5} \\
\text { Kelas Sebaran } & =32 \text { kasus }
\end{aligned}
$$

Jadi, dapat di ketahui bahwa disetiap kelas memiliki rentang kasus sebanyak 32 kasus. Sehingga selanjutnya sebaran penyakit asma yang terjadi di wilayah kerja Puskesmas Mojosongo pada tahun 2016, dapat diolah menjadi informasi berupa peta yang di klasifikasi 5 kelas sebaran penyakit dengan menggunakan sistem informasi Geografis. Yang hasilnya dapat dilihat pada Gambar 9. berikut:

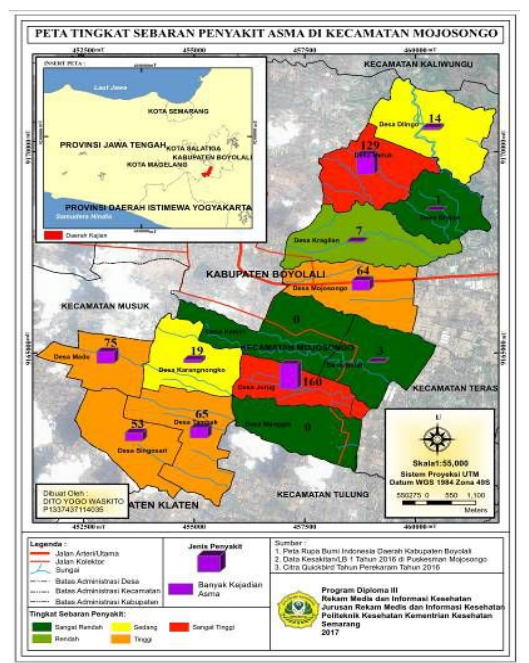

Gambar 9. Peta Sebaran Penyakit Asma 
Sebaran Kasus Konjungtivitis di Puskesmas Mojosongo

Dengan jumlah kasus sebanyak 506 kasus pada periode tahun 2016. Data sebaran kasus asma dapat dilihat pada Tabel 11. berikut:

Tabel 11. Sebaran Kasus Konjungtivitis

\begin{tabular}{clc}
\hline \hline No & \multicolumn{1}{c}{ Desa } & Penyakit (Kasus) \\
& & 0 \\
\hline 1 & Karangnongko & 21 \\
2 & Manggis & 56 \\
3 & Madu & 15 \\
4 & Dlingo & 82 \\
5 & Jurug & 78 \\
6 & Singosari & 56 \\
7 & Tambak & 0 \\
8 & Kragilan & 0 \\
9 & Butuh & 121 \\
10 & Mojosongo & 18 \\
11 & Brajan & 41 \\
12 & Metuk & 18 \\
13 & Kemiri & \\
\hline \hline
\end{tabular}

Penghitungan Kelas dilakukan secara otomatis dalam Arcgis. Dengan berdasarkan rumus equal interval:

$$
\begin{aligned}
& \text { Kelas Sebaran }=\frac{N T \max -N T \min }{5} \\
& \text { Kelas Sebaran }=\frac{121-0}{5} \\
& \text { Kelas Sebaran }=\frac{121}{5} \\
& \text { Kelas Sebaran }=24 \text { kasus }
\end{aligned}
$$

Jadi, dapat di ketahui bahwa disetiap kelas memiliki rentang kasus sebanyak 24 kasus. Sehingga selanjutnya sebaran penyakit konjungtivitis yang terjadi di wilayah kerja Puskesmas Mojosongo pada tahun 2016, dapat diolah menjadi informasi berupa peta yang di klasifikasi 5 kelas sebaran penyakit dengan menggunakan sistem informasi Geografis. Yang hasilnya dapat dilihat pada Gambar 10. berikut:

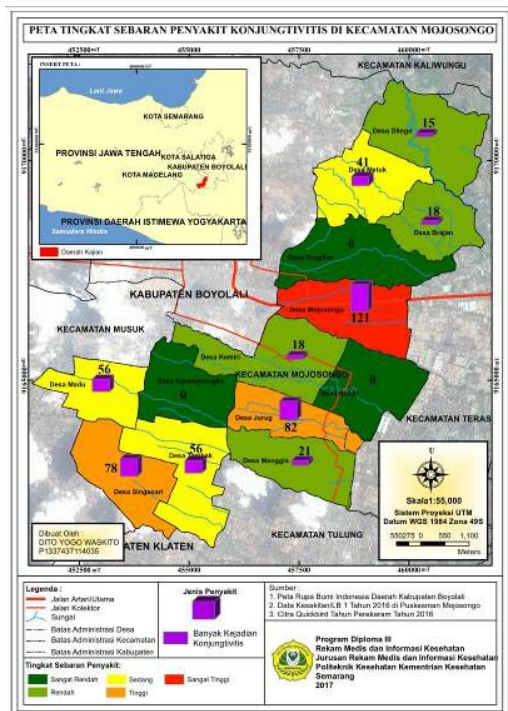

Gambar 10. Peta Sebaran Penyakit Konjungtivitis

Diketahui dari data Tabel 2 sampai Tabel 11 bahwa terdapat sepuluh besar penyakit dengan kasus yang tersebar disetiap desa di wilayah kerja Puskesmas Mojosongo.

Jadi, dapat di ketahui bahwa disetiap kelas memiliki rentang kasus sebanyak 1122 kasus. Sehingga dari data ini dapat diliahat pemetaan sebaran sepuluh besar penyakit dengan Sistem Informasi Geografis di Puskesmas Mojosongo pada tahun 2016 pada Gambar 11. berikut:

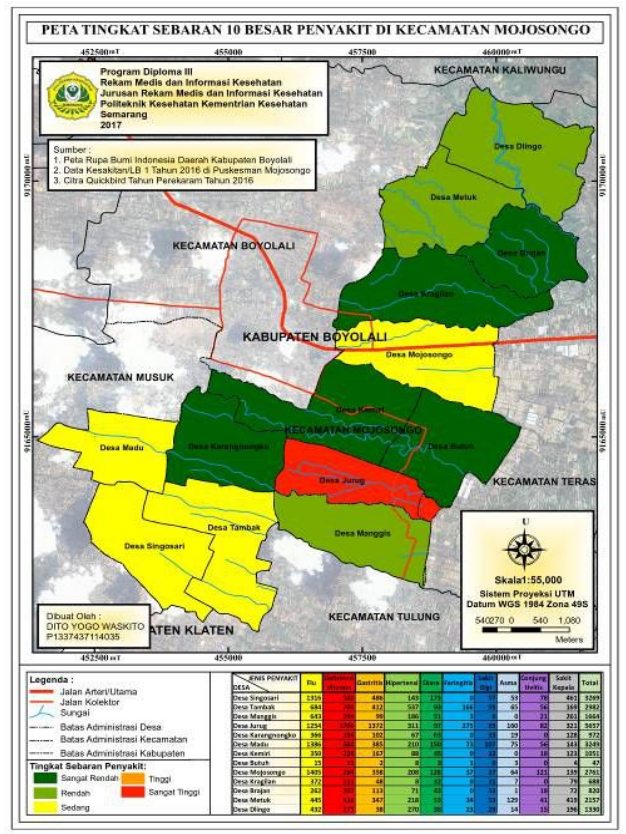

Gambar 11. Peta Sebaran Sepuluh Besar Penyakit 


\section{Simpulan dan Saran}

Berdasarkan kasus penelitian dan pembahasan yang telah dilakukan, maka ditarik kesimpulan sebagai berikut:

a. Dengan peta lebih memudahkan pihak manejemen puskesmas dalam memperoleh gambaran permasalahan penyakit berdasarkan lokasi dan tingkat sebarannya. Sehingga dapat menjadi masukan dan pertimbangan dalam pengambilan keputusan.

b. Desa Jurug menjadi wilayah yang paling sering diklasifikasikan menjadi wilayah yang sering memiliki kejadian kasus sebaran penyakit sangat tinggi. Sedangan desa Butuh menjadi desa paling sering memiliki sebaran penyakit paling rendah.

Berdasarkan pengalaman yang didapat saat melakukan penelitian penulis menyarankan beberapa hal sebagai berikut:

a. Perlu adanya pengembangan penyajian data statistik dengan menggunaan peta, karena sangat mendukung dalam melihat gambaran permasalahan dan intensitas penyakit, dalam upaya pengambilan keputusan.

b. Diperlukannya kelengkapan data kesekitan berupa rincian jenis penyakit yang lebih detail dari setiap puskesmas pembantu di setiap bulannya, untuk memperoleh hasil yang lebih akurat dalam pengolahan data menjadi informasi yang berguna bagi Puskesmas Mojosongo

\section{Ucapan Terimakasih}

Dalam penyusunan penulis banyak mendapat saran, kritik, dorongan, bimbingan serta keterangan - keterangan dari banyak pihak, yang menjadikan penulis dapat menyusun penelitian ini dengan baik dan dapat dipertanggungjawabkan. Oleh karena itu dengan segala hormat dan kerendahan hati perkenankan penulis mengucapkan terimakasih kepada semua pihak yang telah banyak membantu.

\section{Daftar Pustaka}

Ade, Heryana. (2015). Surveilans Epidemiologi Penyakit Menular "Materi Online Class Mata Kuliah Epidemiologi Penyakit Menular". Jakarta: Universitas Esa Unggul.

Departemen Kesehatan (2014). Permenkes RI Nomor 45 tahun 2014. Tentang
Penyelenggaraan Survelans Kesehatan. Jakarta: Departemen Kesehatan.

Departemen Kesehatan (2014). Permenkes RI. Nomor 75 tahun 2014. Tentang Pusat Kesehatan Masyarakat. Jakarta: Departemen Kesehatan.

Departemen Kesehatan. (2008). Permenkes RI. No. 269/MENKES/PER/III/2008. Tentang Rekam Medis. Jakarta: Departemen Kesehatan.

Eddy, Prahasta. (2002). Sistem Informasi Geografis "Konsep - Konsep Dasar". Bandung: Informatika Bandung.

Edy, Prahasta. (2012). System Requirements Untuk ArcGIS 10.1. (online). (http://www.geotekno.com/systemrequirements-untuk-arcgis-10-1/454) diakses tanggal 21 februari 2017.

Gemala R. Hatta. (2013). Pedoman Manajemen Informasi Kesehatan di Sarana Pelayanan Kesehatan Edisi revisi 2. Jakarta: Universitas Indonesia.

Kementerian Kesehatan RI. Sekertariat Jendral. (2015). Rencana Strategi Kementerian Kesehatan Tahun 2015-2019. Jakarta: Kementerian Kesehatan RI.

Kementerian Kesehatan RI. Sekertariat Jendral. (2016). Pedoman Umum Program Indonesia Sehat dengan Pendekatan Keluarga. Jakarta: Kementerian Kesehatan RI.

Masyarakat Penulis Ilmu Pengetahuan dan Teknologi. (2013). Survei dan Pemetaan Nusantara. Cetakan 1. Jakarta: BAKOSURTANAL.

Notoatmodjo, S. (2012). Metodologi Penelitian Kesehatan. Jakarta: Rineka Cipta.

Wasisso, T.Y. (2017). Analisis Pengaruh Perubahan Penggunaan Lahan Terhadap Tingkat Potensi Gerakan Tanah Menggunakan Sistem Informasi Geografis di Kecamatan Mojosongo Kabupaten Boyolali. Surakarta: Universitas Mohammadiyah Surakarta. 